\title{
The organization of the virus-tested planting material production for the grape varieties of the local and foreign selection in Kazakhstan
}

\author{
Saule Kazybayeva ${ }^{1 *}$, Svetlana Dolgikh ${ }^{1}$, Shokan Kulshanov ${ }^{2}$, Marina Urazayeva ${ }^{1}$ and \\ Gulnaz Ushkempirova ${ }^{2}$ \\ ${ }^{1}$ Limited Liability Company "Kazakh Research Institute of Fruit \& Vegetable Growing”, 238/5 str. \\ Gagarin, Almaty, 050060, Kazakhstan \\ ${ }^{2}$ National Joint Stock Company “Kazakh National Agrarian University”, 8 str. Abay, Almaty, 050010, \\ Kazakhstan
}

\begin{abstract}
The intensification of viniculture involves the organization of the virus-tested planting material production, establishment of the basic parent plantings, certification of the virus-tested planting material with the control of genetic stability of the grape plants propagated in tissue culture. The modified nutritional medium was developed for microclonal propagation of vine in vitro with the content of the free amino acids: glycine and glutamine, increasing propagation factor up to $15 \%$ and the number of nodes on microplant up to $27 \%$.
\end{abstract}

\section{Introduction}

The quality of planting material determines the economic efficiency of the winegrowing industry. The vinicultural plantings, established by the revitalized planting material, are distinguished for enhanced resistance to the natural conditions of environment, high productivity and durability.

In the south and south-east of Kazakhstan a series of viral pathogens was discovered in the vineyards: Grapevine vein mosaic (GVM), Grapevine vein banding virus (GVBV), Grapevine fanleaf virus (GFV), Grapevine vein clearing (GVC) and Grapevine yellow mosaic virus (GYMV). The disease damage caused by these pathogens and their significant prevalence requires urgent development of efficient technologies permitting to prevent their further document.

The methods of thermotherapy, chemotherapy and apical meristems are applied at the present time to recover the plants from viral infection [1].

With the aim of creating the healthy grape mother plants of the highest quality categories and their accelerated propagation, the most promising way is microclonal propagation [2].

An important aspect of effective viticulture is obtaining the high-quality virus-free planting material, in which case consideration must be given to such components as ability of seedlings to rooting and the percentage of established plants, their productivity, durability and quality of fruits. [3].

\footnotetext{
* Corresponding author: Saule 567@mail.ru
} 
The most part of the mother plants in grape nurseries are infected with the viral pathogens and phytoplasma [4]. The yield losses due to diseases caused by the viruses may vary from 50 to $100 \%$ [5]. In order to prevent the spread of a viral infection when laying new plantations of horticultural crops, it is recommended to use certified planting material [6]. The basic mother plants free of viral pathogens should be used as a starting material for reproductive seedlings [7]. The most common and effective way to obtain the virus-free planting material is the cultivation of explants from the meristems $[8,9]$.

One of the major aspects of grape propagation in tissue culture is a need to choose the individual growing conditions depending on the variety [10].

The purpose of work is study varietal specificity of table and technical grapes of local and foreign selection during in vitro clonal micropropagation on a transformed nutritional medium grape.

\section{Materials and methods}

To conduct the investigations the genotypes of introduced and locally selected table and wine varieties of grape were taken from the collection of the Limited Liability Partnership "KazNIIPO": Rkatsiteli, Saperavi, Almaly, Iliysky, Bereke, Aligote and those of table line Aisulu, Medeo and Kzyl-Tan.

The methodology of research was implemented according to the generally accepted requirements [11]. The method of obtaining the virus-free plants is based on revitalization with the use of apical meristems of 0.2-0.4 $\mathrm{mm}$ in size [12].

For the sake of exception of chimaeras during the clonal micropropagation of grapes, the microplants grown in tissue culture were estimated with the use of ISSR molecular markers. DNA was extracted from the herborized leaves (20 mg of tissue per specimen) with the use of "Diatom ${ }^{\mathrm{TM}} \mathrm{DNA}$ " sets, following the annexed protocol of Biocom firm. Genotyping the grape specimens involved in the process of work eight ISSR markers: M2- (ac) ${ }_{8} \mathrm{ctg}$; M3(ga) $)_{8}(\mathrm{ct}) \mathrm{c}, \quad$ M4-(ag) $)_{8}(\mathrm{ct}) \mathrm{c}, \quad$ M9-(gac-acg-aca-cga-cac-gac-ac); M8- (gtg)5. M11 (ca)6ag; M12(ca) ${ }_{6}$ agct; UBC 881-ggg-tgg-ggt-ggg-gtg. The synthesis of oligonucleotides was carried out by the firm ZAO "Sintol", Russia. All the markers used in work involved the standard terms and conditions to carry out PCR amplification, permitting to achieve the maximum output of target fragments. The polymerase chain reaction was conducted with the use of Eppendorf thermocycler (Germany) [13].

The program of amplification included the parameters as follows: initial denaturation during 3 minutes at $95{ }^{\circ} \mathrm{C}$, further 35 cycles: denaturation during 30 seconds at $94{ }^{\circ} \mathrm{C}$, annealing primers was carried out at the temperature, chosen for each pair of the primers individually, during 30 seconds, it was followed by the period of synthesis during 40 seconds and at $72^{\circ} \mathrm{C}+$ addition by 2 seconds per each cycle [14]. Annealing of primers proceeded at the temperature as follows: $\mathrm{M} 11-44.8^{\circ} \mathrm{C}, \mathrm{M} 12-49.5^{\circ} \mathrm{C}, \mathrm{M} 2-49.5^{\circ} \mathrm{C}, \mathrm{M} 9-50{ }^{\circ} \mathrm{C}, \mathrm{M} 8-$ $52,7^{\circ} \mathrm{C}, \mathrm{M} 3-52.7^{\circ} \mathrm{C}, \mathrm{M} 4-50.8^{\circ} \mathrm{C}, \mathrm{UBC}-50^{\circ} \mathrm{C}$. The PCR mixture included $(20 \mu \mathrm{l})$ from 10 to $20 \mathrm{ng}$ of the total DNA, $20 \mathrm{pmol}$ of primer and a ready mixture for reaction ("Biocom" firm, Russia), including Hot start Taq DNA-polymerase, DNTP's and MgCl2 with the necessary concentrations, respectively 1 unit of polymerase activity, $200 \mu \mathrm{M}$ and $2.5 \mathrm{mM}$, as well as special PCR-buffer for reaction. In the process of electrophoresis agarose gel was used in $1.7 \%$ concentration with addition of normal strength Tris Borate buffer coloured by ethydium bromide in $0.5 \mu \mathrm{g} / \mathrm{ml}$ concentration at the voltage of $100 \mathrm{~V}$ for 45 minutes with the further photographic documentation of amplicons in ultraviolet light and processing in AdobePhotoshop 7.0 program. The obtained results were analyzed through the use of CrossChecker 2.91 software with transfer of data into binary matrices on the grounds of presence or absence of polymorphous fragments uniform in size [15]. 


\section{Results and discussion}

We developed the modified nutritional medium to secure the improved planting material by the method in vitro.

The stages of developed regulations. The developed regulations comprise the stages as follows. The cuttings of $15-20 \mathrm{~cm}$ in size are harvested from the outwardly healthy vines, then these cuttings are placed in a thermostat with a temperature of $38^{\circ} \mathrm{C}$ (thermotherapy) for the regrowth of vegetative shoots and the subsequent introduction of apexes into tissue culture. The explants are cultured using a modified MS culture medium.

Since the yield of plants obtained as a result of in vitro propagation at the initial stages of plants cultivation depends on efficiency of the explants sterilization, thorough sterilization of the grape apexes was carried out before introduction into tissue culture. To remove the surface contamination effectively when introduced into the tissue culture, irgasan was used as a detergent and diocidum with active chlorine as a detergent. The course of sequential treatment with disinfecting agents of the grape buds during the emergence of the beginning of their vegetation irgasan and diocidum made it possible to exclude contamination. There was observed increase in the size of the apical growth tissues of grapes up to $1-2 \mathrm{~cm}$ in the process of their cultivation in vitro on the liquid nutritional medium for 30 days. Then, another transfer of the regenerants to a liquid nutritional medium was carried out, and with the growth of a grape shoot up to $4 \mathrm{~cm}$ long with 6-8 buds, the shoot was divided into 2-3 microcuts with one or two buds, which were transplanted onto a new nutritional medium. A varietal response was noted at the stage of proliferation, characterized by a propagation factor from 2.9 to 5.8 , depending on the variety (Fig. 1,2). In the case of apexes cultivation on a nutritional medium containing glycine and glutamine, an increase in the multiplication factor by $10-15$ percent was observed. It should be noted that the highest propagation factor per passage on this nutritional medium and in the absence of amino acids in the nutrient medium was 5.6 in Saperavi, and with amino acids in Bereke (7.0) and Saperavi (6.4). Also, the addition of the amino acids of glycine and glutamate to the nutritional medium increased the number of nodes on microplants by an average of $27 \%$.

When the shoots reached the length of more than $1 \mathrm{~cm}$, the microplants were rooted on a modified liquid nutritional medium until the roots were formed, and then they were transferred to ex vitro conditions for their adaptation. To obtain a virus-free planting material for grapes, the plants that had reached standard sizes were planted in a base stock, then they were bedded out by grafting and planted in a reproductive stock.

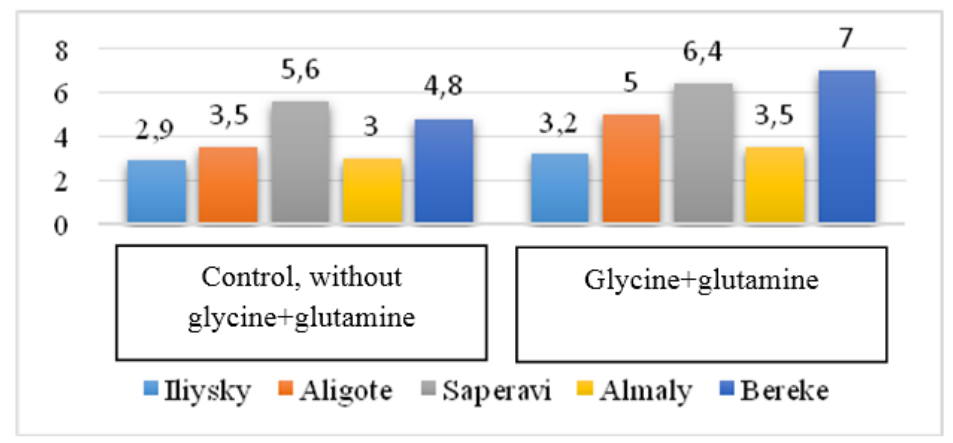

Fig. 1. The dependence of propagation factor on the nutritional media composition on the different grape varieties with 1 passage of explants, pc. 


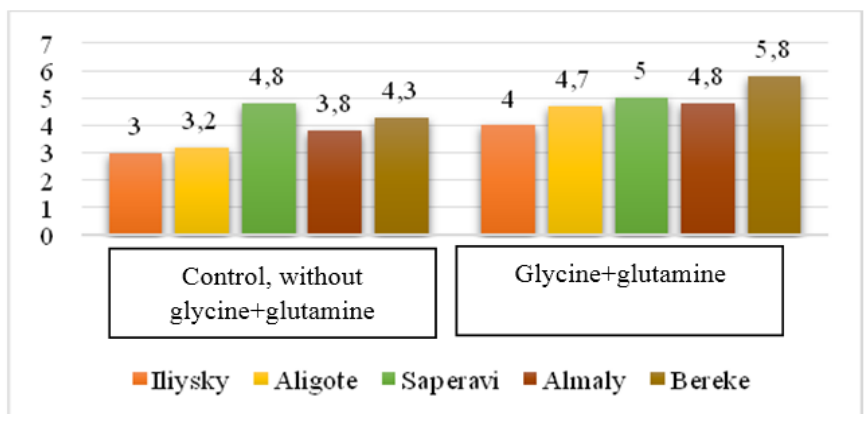

Fig. 2. The dependence of nodes number of the various grape varieties on the nutritional media composition with 1 passage of explants, pc.

When cultivating grapes by in vitro method, we carried out a visual appraisal of varietal purity, and externally suspicious microplants were checked by PCR method with the use of ISSR markers to control the stability of genotypes in order to exclude chimeras (Fig. 3).

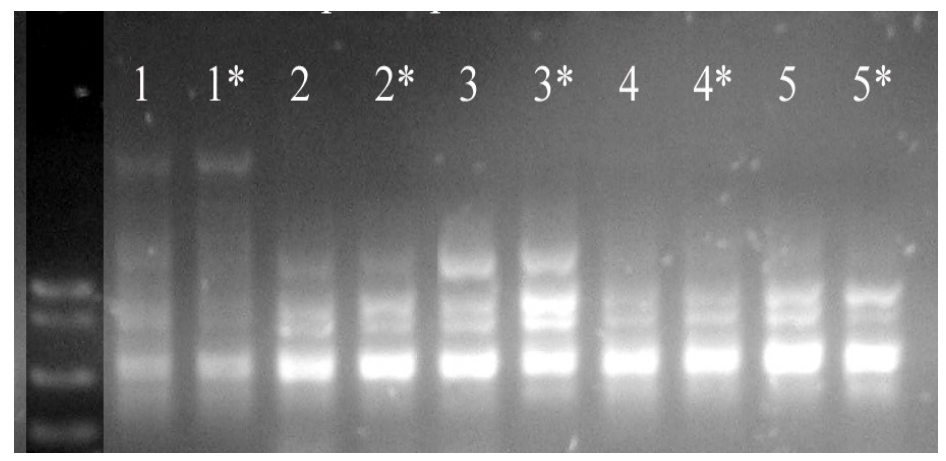

*- meristem plants:

1- Rkatsiteli, 2-Iliysky, 3- Saperavi, 4-Aligote, 5-Almaly

Fig. 3. The results of separating products of PCR amplification of the grape DNA fragments with the use of M2 and M9 primers in agarose gel.

The PCR products of the grape grafters and propagated in vitro within the boundaries of each variety remained unchanged. The obtained results showed the stability in allelic composition of genotypes of original varieties and clonally propagated in vitro.

\section{Conclusion}

The cultivations of apexes on the modified nutritional medium, containing glycine and glutamine, brought to increase in propagation factor by $10-15 \%$ and the number of nodes on microplant up to $27 \%$.

The varietal specificity of the grape genotypes was revealed when the nutrient medium was changed. The highest propagation factor per one passage with the absence of amino acids nutritional medium was 5.6 in Saperavi, and with amino acids in Bereke (7.0) and Saperavi (6.4).

The grape growing by in vitro method in experiment showed the stability in allelic composition of genotypes of the original varieties and clonally propagated in vitro. 


\section{References}

1. S. Yancheva, P. Marchev, V. Yaneva, V. Roichev, Bulgarian Journal of Agricultural Sience, 24(5), 801-806 (2018). URL: https://www.researchgate.net/ publication $/ 329376218$

2. C.Feng, R.Wang, L. Jingwei, B. Wang, Methods in molecular biology, 11013, 463-82 (2013). http://doi.org/10.1007/978-1-62703-074-8_31

3. H. Alzubi, L.M. Yepes, M. Fuchs, International journal of Plant Developmental Biology, 6(1), 9-14 (2012). URL: $\quad$ http://www.globalsciencebooks.info/Online/ GSBOnline/images/2012/IJPDB 6(1)/IJPDB_6(1)9-14o.pdf

4. D. Daurov, K. Zhapar, A. Daurova, D. Volkov, M. Bakbergenova, D. Tolegenova, M. Shamekova, K. Zhambakin, International Journal of Agriculture and Biology, 20(4), 851856 (2018). http://doi.org/ 10.17957/IJAB/15.0576

5. T. Lyubenova, N. Genov, E. Balashkov, N. Prodanova-Marinova, 2nd International Symposium for Agriculture and Food ISAF-2015, 588-598, (2015). URL: https://www.researchgate.net/publication/326266033

6. I. Kamenova, I. Tsvetkov, A. Atanassov, Biotechnology \& Biotechnological Equipment, 21(1), 66-68 (2014). http://doi.org/ 10.1080/13102818.2007.10817416

7. György Bisztray, M. Kolber, J. Lazar, E. Szegedi , International Journal of Horticultural Science, 17(3), 59-63 (2011). http://doi.org/10.31421/IJHS/17/3/958

8. H. Waite, M. Whitelaw-Weckert, P. Torley, New Zealand Journal of Crop and Horticultural Science, 43(2), 2-15 (2014). http://doi.org/10.1080/01140671.2014.978340

9. B. Kinfe, T. Feyssa, G. Bedada, African Journal of Biotechnology, 16(43), 2083-2091 (2017). http://doi.org/10.5897/AJB2016.15803

10. D. Vizitiu, L. Dejeu, I. Radulescu, C. F. Popescu, Scientific Papers, Series B, Horticulture, 56, 2286-1580 (2012). URL: https://www.researchgate.net/ publication $/ 316511303$

11. R. P. Almeida, K. M. Daane, V. A. Bell, G. K. Blaisdell, M. L. Cooper, E. Herrbach, G.Pietersen, Front. Microbiol, 19, (2013). https://doi.org/10.3389/fmicb.2013.00094

12. S. S. Bhojwani, P. K. Dantu, Plant Tissue Culture: An Introductory Text, 227-243 (2013). https://doi.org/10.1007/978-81-322-1026-9_16

13. F. Kimsa, African Journal of Biotechnology, 16(16):852-859 (2017). https://doi.org/10.5897/AJB2016.15717

14. J. C. Bettoni, M. D. Costa, J. Peterson, P. Gardin, A.A. Kretzschmar, R. Pathirana, Rev. Bras. Frutic., 38(2), 1-13 (2016). https://doi.org/10.1590/0100-29452016833

15. C. Bayoudh, E. Manel, R. Labidi, A. Majdoub, The plant pathology journal, 33(3), 288295 (2017). https://doi.org/10.5423/PPJ.OA.10.2016.0205 